\title{
Robotic nipple sparing mastectomy through a single incision: Advantages of starting with posterior dissection
}

\author{
Cihan Uras ${ }^{1,2,3}$ (D), Akif Enes Arıkan 1,2,3 (D), Halil Kara ${ }^{2,3,4}$ (D), Onur Dülgeroğlu ${ }^{2,4,5}$ (D), Yakup Avşar ${ }^{6}$ (D) \\ ${ }^{1}$ Acibadem Mehmet Ali Aydinlar University, School of Medicine, Department of General Surgery, Istanbul, Turkey \\ ${ }^{2}$ Acibadem Mehmet Ali Aydinlar University, Research Institute of Senology, Istanbul, Turkey \\ ${ }^{3}$ Acibadem Maslak Hospital, Department of General Surgery, Division of Breast Health and Diseases, Istanbul, Turkey \\ ${ }^{4}$ Acibadem Mehmet Ali Aydinlar University, Vocational School of Health Sciences, Istanbul, Turkey \\ ${ }^{5}$ Acibadem Atakent Hospital, Department of General Surgery, Division of Breast Health and Diseases, Istanbul, Turkey \\ ${ }^{6}$ Private Avşar Clinic, Istanbul, Turkey
}

\section{ABSTRACT}

Objective: Loss of breast, which is an important body marking of women, causes a huge decrease in quality of life (QoL) after treatment. In order to overcome this morbidity and increase QoL, nipple sparing mastectomy (NSM) has been developed. Even though the demand for better cosmetic results has yielded endoscopic nipple sparing mastectomy, limitations like unsuitable optical window and limited manual control of rigid-tip instruments, and struggling to keep dissection space have led robotic nipple sparing mastectomy (rNSM) to be developed.

Material and Methods: Records of three patients who underwent to rNSM for invasive breast carcinoma with DaVinci Xi (Intuitive Surgical, Sunnyvale, (A) in affiliated hospitals of Acıbadem Mehmet Ali Aydınlar University, Research Institute of Senology in 2018 were investigated retrospectively. In all breasts $(n=4)$, dissection was started from the posterior side of breast.

Results: In the unit, 738 breast cancer patients underwent surgery between 2018 and 2019 with an NSM ratio of 31.4\% ( $n=232$ ). Of these patients, three underwent rNSM with DaVinci Xi robotic system. The operation was performed on the left breast in one patient, right in one, and bilateral in one patient. Only in patient \#2, who was a neoadjuvant chemotherapy recipient, seroma was observed six weeks after surgery ( 3 weeks after removal of drains) and spontaneously resolved in 4 weeks. No other complication was seen in all patients. In the follow-up period of median 21 months, no loco-regional recurrence or distant metastasis was seen.

Conclusion: A single incision robotic mastectomy can be performed easily and safely when the dissection starts from the pre-pectoral plane rather than the subcutaneous plane.

Keywords: Breast, robotic surgical procedure, minimally invasive surgical procedures

Cite this article as: Uras C, Arıkan AE, Kara H, Dülgeroğlu $\mathrm{O}$, Avşar Y. Robotic nipple sparing mastectomy through a single incision: advantages of starting with posterior dissec tion. Turk J Surg 2020; 36 (3): 303-309.

\section{Corresponding Author}

Akif Enes Arıkan

E-mail: enesarikan@yahoo.com

Received: 23.03 .2020

Accepted: 24.04 .2020

Available Online Date: 28.09 .2020

(o Copyright 2020 by Turkish Surgical Society Available online at www.turkjsurg.com

DOI: 10.47717/turkjsurg.2020.4771

\section{INTRODUCTION}

In early periods, radical mastectomy (i.e. extended removal of the breast and neighboring tissues) was considered as the ultimate treatment (1). However, advancements in medical oncology and surgical technique (such as proven safety and efficiency with the protection of pectoral muscles and even the skin with or without nipple areolar complex in appropriate cases, tools with increased precision) have provided surgeons and patients with a better cosmetic outcome (2). Loss of breast, which is an important body marking of women, causes a huge decrease in quality of life (QoL) after treatment (2). In order to overcome this morbidity and increase QoL, nipple sparing mastectomy (NSM) has been developed (2). After proven oncological safety, patients and surgeons demanded better cosmetic results which yielded endoscopic nipple sparing mastectomy (eNSM) $(2,3)$. Even though eNSM was facilitated by many authors with oncological safety, limitations like unsuitable optical window due to two-dimensional endoscopic in-line camera and limitations in manual control of rigid-tip instruments by the natural curvature of the breast, and struggling to keep dissection space, robotic nipple sparing mastectomy (rNSM) was developed in Milan, in August of 2015 (4).

The search from the Web of Science (WOS) database for "robotic" and "mastectomy" words yielded 58 results; however, only 25 of them were related to robotic nipple sparing mastectomy (4-28).

In the literature, eight studies have investigated rNSM through single incision for therapeutic or prophylactic purposes $(5,6,9,21,22,26-28)$. The current study is 
the first report of rNSM from Turkey and showed a different approach from the literature.

\section{MATERIAL and METHODS}

Records of three patients who underwent to rNSM for invasive breast carcinoma with DaVinci Xi (Intuitive Surgical, Sunnyvale, CA) (robot) in Acıbadem Maslak Hospital (an affiliation of Acıbadem Mehmet Ali Aydınlar University, Research Institute of Senology) in 2018 were investigated retrospectively. Demographics and operative and histopathology information of the patients were recorded. All patients had given informed consent for rNSM prior to surgery independent from this study.

This study was approved by Acıbadem Mehmet Ali Aydınlar University, Clinical Research Evaluation Ethical Board on 27.06.2019 with number of 2019-11/24.

\section{Patient Positioning}

All surgical procedures were performed under general anesthesia. Patient lied flat supine, contralateral arm to operation side was adducted, a soft pad was placed under the ipsilateral scapula, and ipsilateral arm was positioned over the head covered with sterile covering (Figure 1). The table was positioned in $5^{\circ}$ tilted to the contralateral side.

\section{Set-up of the Robotic System}

The robot was positioned at the opposite side of the patient, middle of the robot's shoulder positioned to the nipple line, and arms crossed over the torso of the patient. Target markings of the robot was aligned with the incision and the nipple. Three ports of the robot were introduced through a single access system (SAS) in triangular setting to prevent collision and sustain better approximation (Figure 2). A monopolar cautery attached scissor was placed on the right arm and a bipolar cautery attached fenestrated forceps was placed on the left arm of the robot. A $30^{\circ}$ camera (Intuitive Surgical ${ }^{\oplus}$, Denzlingen, Germany) was introduced through the port in the top center. Following

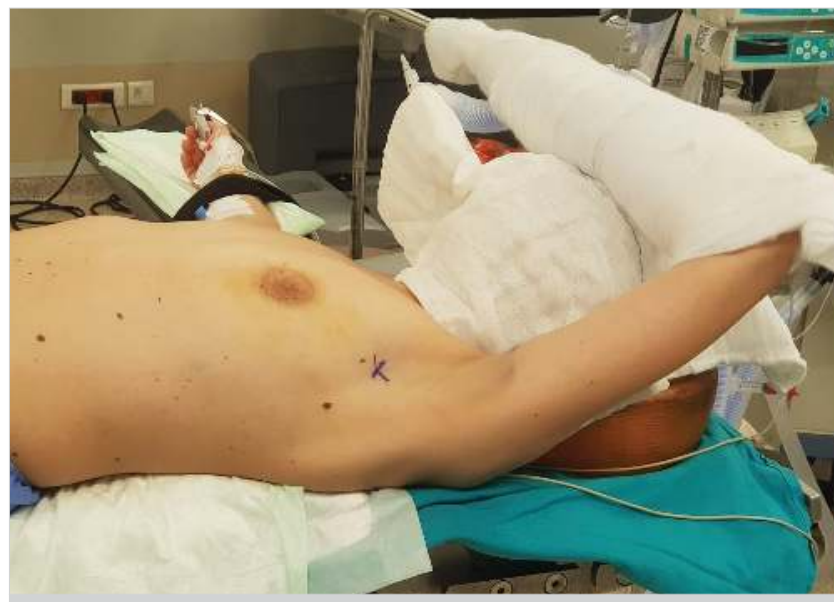

Figure 1. Position of the patient on the operation table. that, the other two instruments were introduced to the pouch under camera vision.

While the surgeon was sitting in the console, the assistant surgeon was waiting next to the patient to watch over the robot arms and trans-illumination (visual observation) through the breast skin to prevent injuries.

\section{Surgical Technique}

A 5-cm lateral peripheral incision starting from the middle portion of the breast to the cranial direction, positioned on the anterior axillary line in parallel to the curvature of the breast, was performed (Figure 3, 4). Sentinel lymph node biopsy (SLNB)

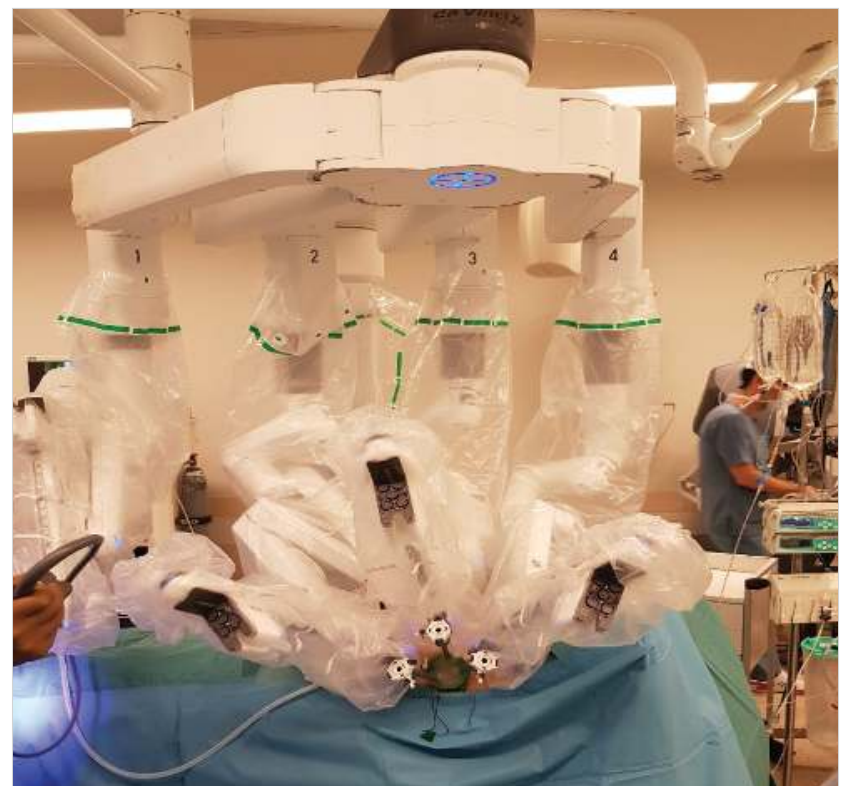

Figure 2. Docking of the Da Vinci Xi Robotic System.

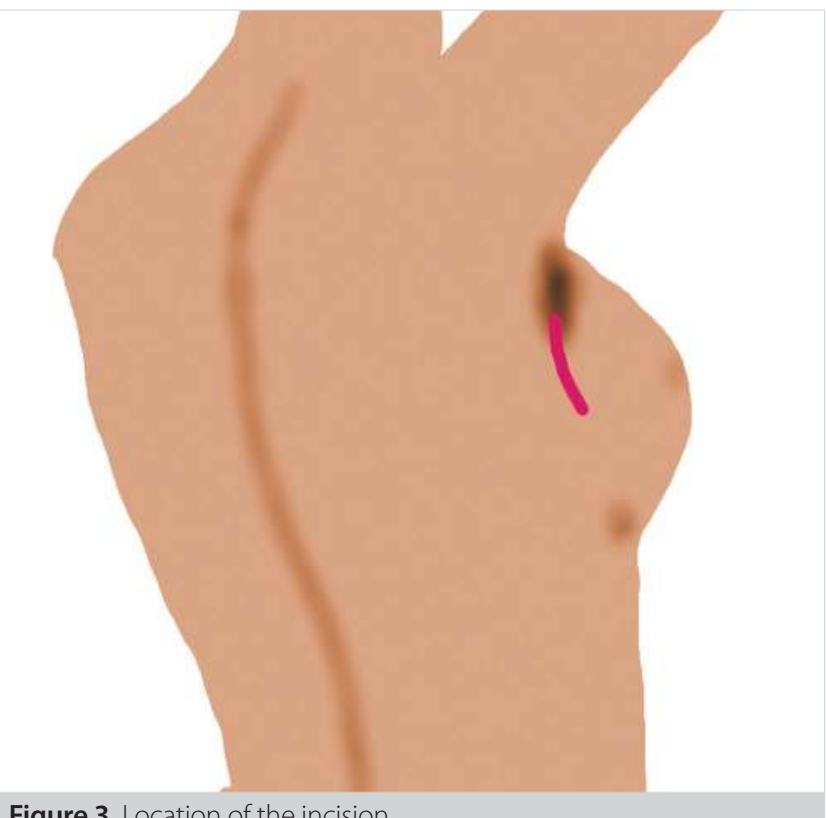

Figure 3. Location of the incision 


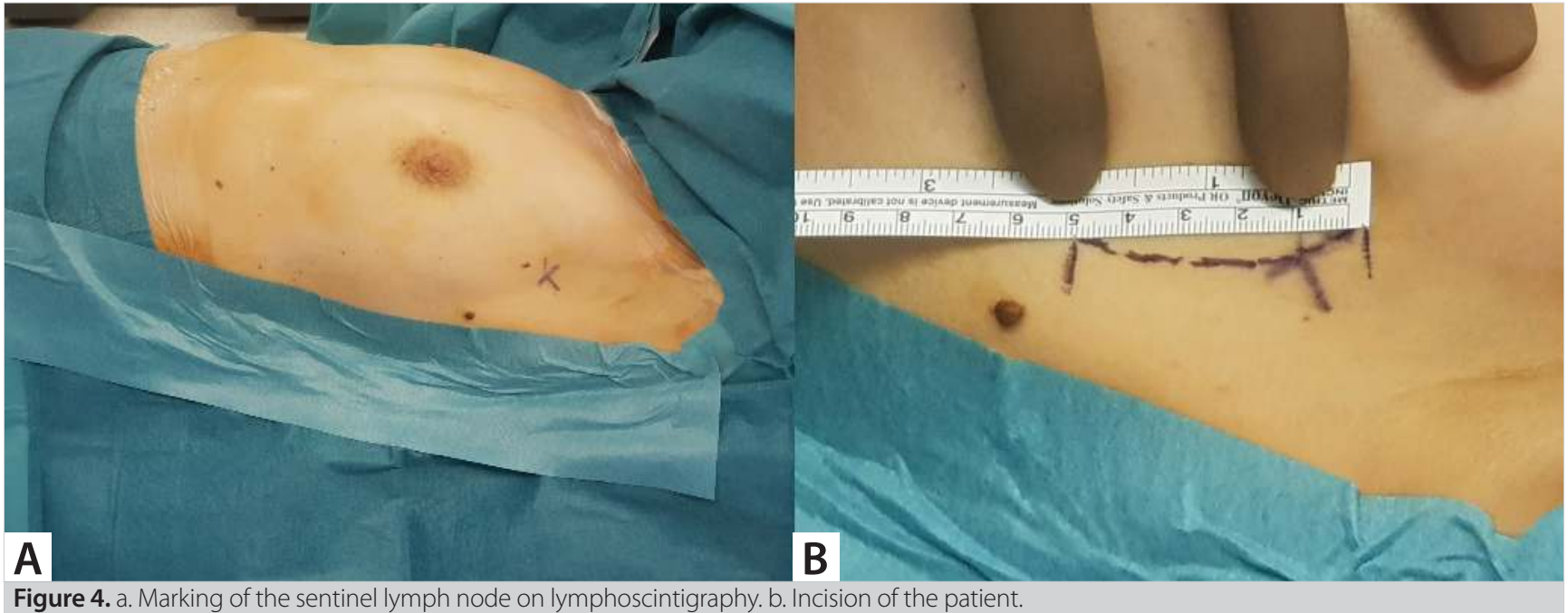

was performed through this incision with conventional open technique via radioisotope method. The incision was planned to allow axillary lymph node dissection (ALND) through the same incision after removal of the breast tissue, in case SLNB resulted positive.

After SLNB, a pouch, 3-cm in length, was dissected between the fascia and anterior side of the pectoralis muscle with Bouvie cautery to introduce SAS. After that, GelPOINT Mini (Applied Medical, Rancho Santa Margarita, CA) was positioned as SAS to the pouch, and the posterior cavity was insufflated with $\mathrm{CO} 2$ gas at a pressure of $6 \mathrm{mmHg}$ (Figure 5).

Posterior side of the breast was dissected with electrocautery attached scissor, while the breast tissue was handled with fenestrated forceps (Figure 6). Extension of the dissection was observed externally by the assistant surgeon next to the patient. Caution for the preservation of the perforating branch from the $2^{\text {nd }}$ intercostal artery was sustained to reduce risk for loss of nipple areolar complex (NAC).

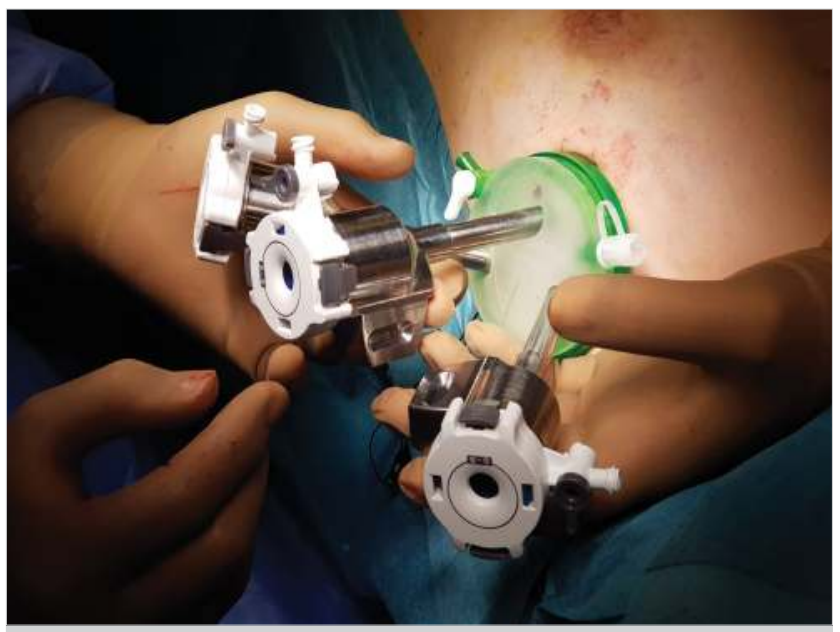

Figure 5. Positioning of the air sealing system and robotic ports.
After having completed the posterior dissection, the robotic system was undocked and SAS removed. In order not to cause ischemia, 500 mcg of adrenaline was diluted in $1000 \mathrm{~mL}$ 0.9\% $\mathrm{NaCl}$ solution as tumescent solution (TS). Two-hundred milliliters of TS was injected to the subdermal layer of the breast skin by liposuction cannula to sustain hydro-dissection between the skin and breast tissue with additional effect of vasoconstriction to lower bleeding. After that, an anterior pouch between the skin and breast tissue for SAS was created with scissor under direct vision and SAS was placed similarly. The anterior cavity was insufflated with $\mathrm{CO}_{2}$ gas at a pressure of 6 $\mathrm{mmHg}$ (Figure 7), and dissection was performed with scissor and fenestrated forceps. Retro-nipple breast tissue was coredout and sent to frozen section assessment for malignant cells. If malignancy was detected in the frozen section, then NAC was removed.

After completion of NSM, an implant (either silicone-gel or expender according to the necessity of radiotherapy depending on the result of SLNB) was placed by a plastic, reconstructive and esthetic surgeon through the same incision.

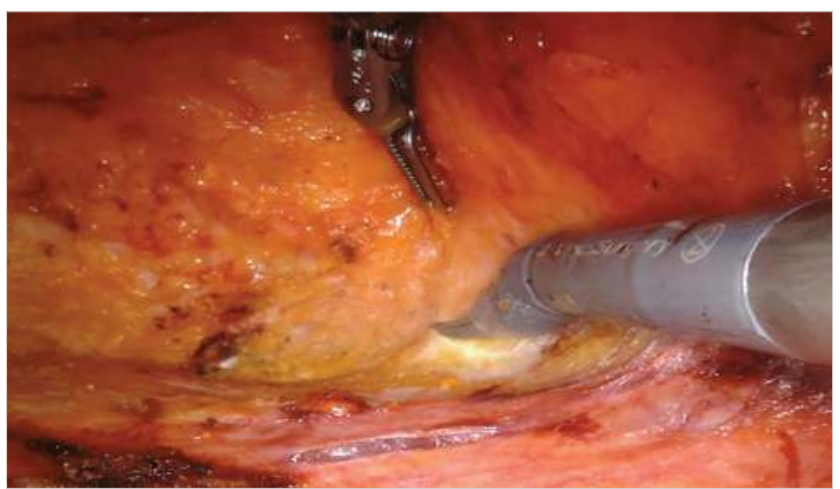

Figure 6. View of the posterior dissection by the Da Vinci Xi robotic System. 


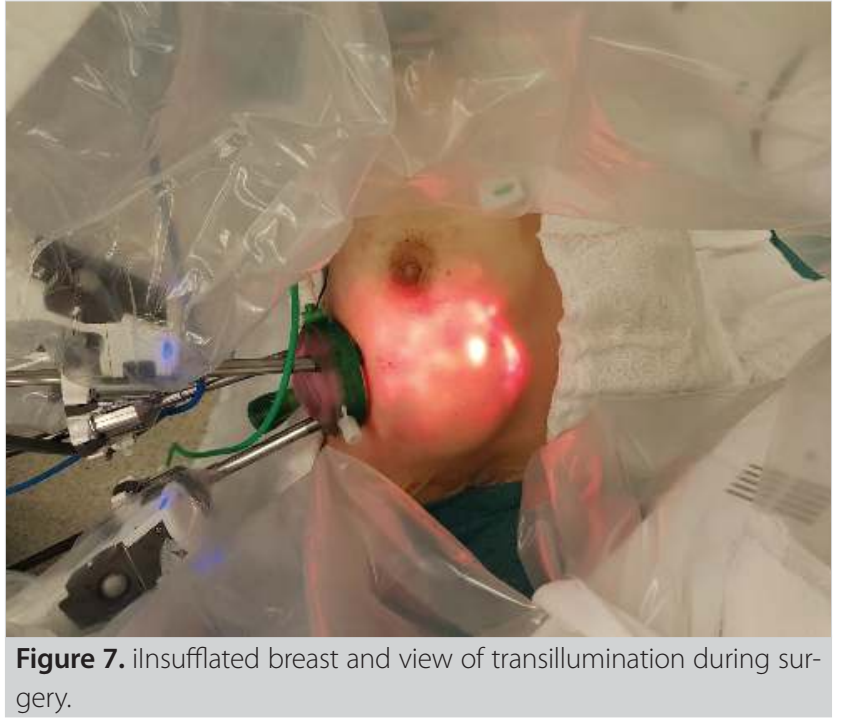

\section{RESULTS}

In the Breast Unit, 738 breast cancer patients underwent surgery between 2018 and 2019 with an NSM ratio of $31.4 \%$ ( $n=232)$. Of these patients, three underwent robotic nipple sparing mastectomy with the DaVinci Xi robotic system. All patients were females.

All three patients were operated on for breast carcinoma. Patient \#2 received neoadjuvant chemotherapy. The operation was performed on the left breast in one patient, right in one, and bilateral in one patient (patient \#1). All patients underwent SLNB (patient \#1 underwent SLNB only on the malignant side); however, ALND was not performed in any of the patients. Median age was 43 (3847) years, median docking time (anterior and posterior in total) was 12 (10-15) minutes, median anterior dissection time was 86 (60-108) minutes, and median posterior dissection time was 32 (30-39) minutes. Median length of the rNSM was 134 (105-161) minutes. In the pathology report, all margins were clear and far from the tumor, and the retro-nipple tissue was free from tumor. None of the patients were converted to another technique, no complications observed, and no subcutaneous shaving needed. All patients were admitted on the morning of the operation day and stayed two nights after surgery. In the pathology report, the average tumor size was $25.7 \pm 9 \mathrm{~mm}$, margins were negative, estrogen receptor positivity was $67 \pm 58 \%$, and Ki-67 score was $49 \pm 44 \%$. In all patients, progesterone receptor was negative and human epidermal growth factor receptor 2 (Her-2) was negative in two patients. Only in patient \#2 (who received neoadjuvant chemotherapy due to axillary lymph node involvement), seroma was observed six weeks after surgery (3 weeks after the removal of drains) and spontaneously resolved in 4 weeks. No other complication was seen in all patients. In the follow-up period of median 21 (range: 19-24) months, no loco-regional recurrence nor distant metastasis was seen. Data of each patient is given in Table 1 and Table 2.

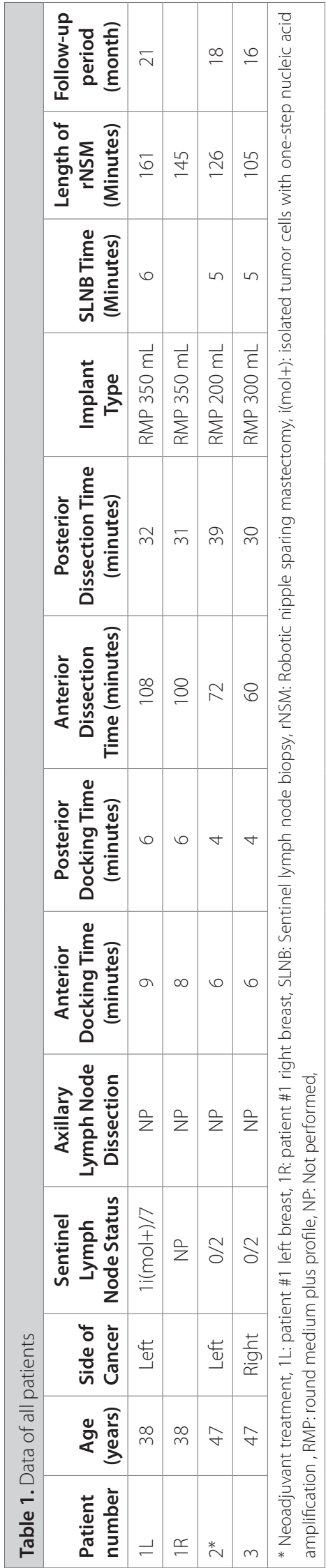


Table 2. Pathology results of all patients

\begin{tabular}{|l|c|c|c|c|c|c|c|c|c|c|}
\hline Patient & Type of cancer & $\begin{array}{c}\text { Tumor Size } \\
\text { (millimeters) }\end{array}$ & $\begin{array}{c}\text { Nuclear } \\
\text { Grade }\end{array}$ & $\begin{array}{c}\text { Histological } \\
\text { Grade }\end{array}$ & ER (\%) & PR (\%) & Her-2 & Ki-67 (\%) & cTNM & pTNM \\
\hline 1 & IDC & 17 & 3 & 3 & 0 & 0 & 0 & 80 & cT1cN0M0 & pT1cN0(mol+) \\
\hline 2 & DCIS & 25 & $3^{*}$ & & $100^{*}$ & 0 & NP & NP & cTisN1M0* & ypTisN0 \\
\hline 3 & IDC & 35 & 2 & 2 & 100 & 0 & 0 & 18 & cT1cN0M0 & PT1bN1a \\
\hline
\end{tabular}

*Prior to neoadjuvant chemotherapy, IDC: Invasive ductal carcinoma, DCIS: Ductal carcinoma in situ, ER: Estrogen receptor, PR: Progesterone receptor, NP: Not performed, cTNM: Clinical TNM classification, pTNM: pathological TNM classification.

\section{DISCUSSION}

The search from the Web of Science (WOS) database for "robotic" and "mastectomy" words yielded 58 results; however, only 25 were related with robotic nipple sparing mastectomy (4-28). Of these 25 articles, six were congress abstracts (4,11-15), five were letters to the editor (16-20), six were case reports(5-10), and eight were original articles. Of these 14 articles (case reports and original articles), when institute of the first or majority of the authors was assumed as the origin of country, eight (57\%) were originated from Asia (seven from Far East) and six (43\%) were from Europe (one (7\%) was co-authored from the USA).

The center where the operations were performed has a volume of 1688 breast cancer surgeries, in which $35 \%(n=590)$ was NSM in a period of 4 years.

In the current literature, eight studies investigated rNSM through a single incision for therapeutic or prophylactic purposes. In all of these articles, authors (three different first authors: Lai H, Park $\mathrm{H}$, and Toesca A) preferred to start the dissection from the subcutaneous side of the breast. Toesca, A et al. (21) and Lai, $\mathrm{H}$ et al. (22) have mentioned that it is needed to pull up the breast to create sufficient working space during the dissection of the breast tissue from the pectoralis major muscle, and even they insufflated the cavity with $\mathrm{CO}_{2}$ gas at a $8 \mathrm{mmHg}$ pressure. In addition, Park, $\mathrm{H}$ (6) has presented a gasless technique and used a special retractor (Modified Chung's retractor) to create space.

In NSM, it is important to preserve the integrity of the skin and pectoralis muscle. Skin integrity is required to prevent necrosis, and pectoralis muscle integrity is required to preserve the retroprectoral positioned implant. It is known that direct contact of the implant with the skin will result with erosion of the skin and exposure of the implant to the atmosphere with time. There are other precautions such as the use of acellular dermal matrix; however, cost and seroma formation increase (29).

In the present study, dissection was first performed between the breast tissue and pectoralis major muscle. By this way, breast tissue is not separated from the skin and insufflated $\mathrm{CO}_{2}$ stays only on the posterior of the breast, and thus, even a 6-mm $\mathrm{Hg}$ pressure is enough to create space for dissection. Since the breast tissue is still attached to the skin, posterior dissection can be performed more precisely without injuring the pecto- ralis major muscle and bleeding. A stable breast tissue eases direct visualization of the second intercostal artery, which is an important blood supply to NAC, during dissection. Anterior dissection is performed after completion of the posterior dissection. Due to lower $\mathrm{CO}_{2}$ pressure, breast gland will hang down from the skin with its own weight, and anterior dissection can be easily performed by scissor with aid of fenestrated forceps. In addition to not rising the breast tissue, complications related to air pressure, such as pneumothorax, subcutaneous emphyse$\mathrm{ma}$, and hypercarbia can be prevented with lower $\mathrm{CO}_{2}$ pressure (6). Extend of the dissection is observed by the assistant via palpation and trans-illumination.

While performing NSM with conventional retractors, surgeons cannot easily visualize upper quadrants through infra-mammarian fold incision. Endoscopic mastectomy, with/without insufflation, can be performed with rigid tools; however, visibility and access decrease during dissection beyond the dome of the breast, but with DaVinci Xi robotic system, these restrictions can be avoided $(21,23,28)$.

Seroma was the only complication encountered in the current study, and similarly, Toesca et al. (28) have reported seroma as the most common complication. Even though patient number was small, the only complication was observed in the patient who received systemic treatment as first-line. Although we are aware that this cannot be concluded from the current study, when experience from NSM is adjoined and when first line treatment is systemic treatment, then complication increases after NSM, contrary to the literature (30).

Lai et al. (26) have utilized a higher and oblique incision located in the axilla, Toesca et al. (21) have performed the incision in the axilla on the mid axillary line, and Park et al. (6) have performed a vertical incision on the anterior axillary line but did not mention the exact position. Sarfati et al. (23) have performed the incision on the projection of the bra and proposed it could be hidden easily by the patient; however, the surgery was not performed with single incision. In this study, a 5-cm lateral peripheral incision starting from the middle portion of the breast to the cranial direction, which is positioned on the anterior axillary line in parallel to curvature of the breast, was performed. Since the incision stays on the outer border of the breast, it is hidden 
and with this position, it is both easy to access upper and lower quadrants in addition to medial portion of the breast and SLNB can still be performed.

\section{CONCLUSION}

A single incision robotic mastectomy can be performed easily and safely when the dissection starts from the pre-pectoral plane rather than the subcutaneous plane. It is important to hide the scar to improve QoL of the patient either by positioning it more laterally or on the natural curves, but it must not harden surgery.

Ethics Committee Approval: Ethics committee approval was received for this study from Clinical Research Evaluation Ethical Board (2019-11/24).

Peer-review: Externally peer-reviewed.

Author Contributions: Concept - C.U., A.E.A, H.K., O.D., Y.A.; Design - C.U., A.E.A, H.K.; Supervision - C.U., Y.A.; Resource - C.U., A.E.A, H.K., O.D., Y.A.; Materials - C.U., Y.A.; Data Collection and/or Processing - A.E.A., H.K., O.D.; Analysis and Interpretation - A.E.A., O.D.; Literature Review - H.K., O.D.; Writing Manuscript - C.U., A.E.A, H.K., O.D., Y.A.; Critical Reviews - C.U., A.E.A, H.K., O.D., Y.A.

Conflict of Interest: The authors declared no conflicts of interest or financial ties to disclose.

Financial Disclosure: The authors declared that this study has received no financial support.

\section{REFERENCES}

1. Atkins H. Radical mastectomy. Br J Surg 1948; 36: 87-90. [CrossRef]

2. Headon HL, Kasem A, Mokbel K. The oncological safety of nipplesparing mastectomy: a systematic review of the literature with a pooled analysis of 12,358 procedures. Arch Plast Surg 2016; 43: 328-38. [CrossRef]

3. Sakamoto N, Fukuma E, Higa K, Ozaki S, Sakamoto M, Abe S, et al. Early results of an endoscopic nipple-sparing mastectomy for breast cancer. Indian J Surg Oncol 2010; 1: 232-9. [CrossRef]

4. Toesca A, Manconi A, Peradze N, Loschi P, Panzeri R, Granata M, et al. Preliminary report of robotic nipple-sparing mastectomy and immediate breast reconstruction with implant. Eur J Cancer Congress Abstract 2015; 51: S309-S. [CrossRef]

5. Lai HW, Lin SL, Chen ST, Lin YL, Chen DR, Pai SS, et al. Robotic nipple sparing mastectomy and immediate breast reconstruction with robotic latissimus dorsi flap harvest - Technique and preliminary results. J Plast Reconstr Aesthet Surg 2018; 71: e59-e61. [CrossRef]

6. Park HS, Kim JH, Lee DW, Song SY, Park S, Kim SI, et al. Gasless robotassisted nipple-sparing mastectomy: a case report. J Breast Cancer 2018; 21:334-8. [CrossRef]

7. Rajappa SK, Kumar R, Garg S, Ram D. Robotic nipple-sparing mastectomy: the first experience from Indian subcontinent. Breast J 2018; 24: 1114-5. [CrossRef]

8. Sarfati B, Honart JF, Leymarie N, Rimareix F, Al Khashnam H, Kolb F. Robotic da Vinci Xi-assisted nipple-sparing mastectomy: first clinical report. Breast J 2018; 24: 373-6. [CrossRef]

9. Ahn SJ, Song SY, Park HS, Park SH, Lew DH, Roh TS, et al. Early experiences with robot-assisted prosthetic breast reconstruction. Arch Plast Surg 2019; 46: 79-83. [CrossRef]
10. Kuo C, Sukortseva NS, Sinelnikov ME, Nassilevsky PA, Reshetov IV. A case of breast surgery with da vinci si robotics. Revista Latinoamericana De Hipertension Case Report 2019; 14: 70-3. [CrossRef]

11. Toesca A, Peradze N, Manconi A, Lichosik D, Rietjens M, Veronesi P. Robotic nipple sparing mastectomy and immediate breast reconstruction: Future prospectives for breast cancer surgery. Eur J Cancer Congress Abstract 2016; 57: S72-S. [CrossRef]

12. Sarfati B, Struk S, Leymarie N, Honart JF, Mazouni C, Rimareix F, et al. Robotic nipple-sparing mastectomy with immediate prosthetic breast reconstruction: A prospective study. Eur J Cancer Congress Abstract 2018; 92: S32-S. [CrossRef]

13. Sarfati B, Struk S, Leymarie N, Honart JF, Rimareix F, Delaloge S, et al. Robotic nipple-sparing mastectomy with immediate prosthetic breast reconstruction: A preliminary study. Cancer Res Congress Abstract 2018; 78(4). [CrossRef]

14. Lai HW, Chen ST, Chen DR, Kuo SJ. Comparison of robotic nipple sparing mastectomy (R-NSM) to endoscopic assisted nipple sparing mastectomy (E-NSM) in the management of breast cancer. Cancer Res Congress Abstract 2019; 79(4). [CrossRef]

15. Lee J, Park HS, Kim JH, Lee DW, Song SY, LeW DH, et al. A prospective pilot study of simultaneous robotic assisted nipple sparing mastectomy and immediate reconstruction. Cancer Res Congress Abstract 2019; 79(4). [CrossRef]

16. Sarfati B, Honart JF, Leymarie N, Kolb F, Rimareix F. Robotic-assisted nipple sparing mastectomy: a feasibility study on cadaveric models. J Plast Reconstr Aesthet Surg 2016; 69: 1571-2. [CrossRef]

17. Toesca A, Peradze N, Galimberti V, Manconi A, Intra M, Gentilini O, et al. Robotic nipple-sparing mastectomy and immediate breast reconstruction with implant: first report of surgical technique. Ann Surg 2017; 266: e28-e30. [CrossRef]

18. Struka S, Leymarie N, Honart JF, Missistrano A, Kolb F, Rimareix F, et al. Robotic nipple-sparing mastectomy with immediate reconstruction by robotically harvested latissimus dorsi muscle in a single position: Cadaveric study. Journal of Plastic Reconstructive and Aesthetic Surgery Letter 2018; 71: 764-6. [CrossRef]

19. Lai HW. Robotic nipple-sparing mastectomy and immediate breast reconstruction with gel implant. Ann Surg Oncol 2019; 26: 53-4. [CrossRef]

20. Selber JC. Robotic nipple-sparing mastectomy: the next step in the evolution of minimally invasive breast surgery. Ann Surg Oncol 2019; 26: 10-1. [CrossRef]

21. Toesca A, Peradze N, Manconi A, Galimberti V, Intra M, Colleoni M, et al. Robotic nipple-sparing mastectomy for the treatment of breast cancer: feasibility and safety study. Breast 2017; 31:51-6. [CrossRef]

22. Lai HW, Lin SL, Chen ST, Chen SL, Lin YL, Chen DR, et al. Robotic nipplesparing mastectomy and immediate breast reconstruction with gel implant. Plast Reconstr Surg Glob Open 2018; 6: e1828. [CrossRef]

23. Sarfati B, Struk S, Leymarie N, Honart JF, Alkhashnam H, de Fremicourt KT, et al. Robotic prophylactic nipple-sparing mastectomy with immediate prosthetic breast reconstruction: a prospective study. Ann Surg Oncol 2018; 25: 2579-86. [CrossRef]

24. Sarfati B, Struk S, Leymarie N, Honart JF, Alkhashnam H, Kolb F, et al. robotic nipple-sparing mastectomy with immediate prosthetic breast reconstruction: surgical technique. Plast Reconstr Surg 2018; 142: 6247. [CrossRef] 
25. Houvenaeghel G, Bannier M, Rua S, Barrou J, Heinemann M, Van Troy $A$, et al. Breast cancer robotic nipple sparing mastectomy: evaluation of several surgical procedures and learning curve. World I Surg Oncol 2019; 17:27. [CrossRef]

26. Lai HW, Chen ST, Lin SL, Chen CJ, Lin YL, Pai SH, et al. robotic nipplesparing mastectomy and immediate breast reconstruction with gel implant: technique, preliminary results and patient-reported cosmetic outcome. Ann Surg Oncol 2019; 26: 42-52. [CrossRef]

27. Lai HW, Wang CC, Lai YC, Chen CJ, Lin SL, Chen ST, et al. The learning curve of robotic nipple sparing mastectomy for breast cancer: an analysis of consecutive 39 procedures with cumulative sum plot. Eur J Surg Oncol 2019; 45: 125-33. [CrossRef]
28. Toesca A, Invento A, Massari G, Girardi A, Peradze N, Lissidini G, et al. Update on the feasibility and progress on robotic breast surgery. Ann Surg Oncol 2019; 26: 3046-51. [CrossRef]

29. Yang JY, Kim CW, Lee JW, Kim SK, Lee SA, Hwang E. Considerations for patient selection: prepectoral versus subpectoral implant-based breast reconstruction. Arch Plast Surg 2019; 46: 550-7. [CrossRef]

30. Bartholomew AJ, Dervishaj OA, Sosin M, Kerivan LT, Tung SS, Caragacianu DL, et al. Neoadjuvant chemotherapy and nipple-sparing mastectomy: timing and postoperative complications. Ann Surg Oncol 2019; 26:2768-72. [CrossRef]

\title{
ORIJINAL ÇALIŞMA-ÖZET
}

Turk J Surg 2020; 36 (3): 303-309

\section{Tek kesiden robotik meme başı koruyucu mastektomi: Arka taraf diseksiyonu ile başlamanın avantajı}

\author{
Cihan Uras ${ }^{1,2,3}$, Akif Enes Arıkan ${ }^{1,2,3}$, Halil Kara ${ }^{2,3,4}$, Onur Dülgeroğlü ${ }^{2,4,5}$, Yakup Avşar ${ }^{6}$ \\ ${ }^{1}$ Acıbadem Mehmet Ali Aydınlar Üniversitesi, Genel Cerrahi Anabilim Dalı, İstanbul, Türkiye \\ ${ }^{2}$ Acıbadem Mehmet Ali Aydınlar Üniversitesi, Senoloji Araştırma Enstitüsü, İstanbul, Türkiye \\ ${ }^{3}$ Acıbadem Mehmet Ali Aydınlar Üniversitesi, Genel Cerrahi Kliniği, Meme Sağlığı ve Hastalıkları Bölümü, İstanbul, Türkiye \\ ${ }^{4}$ Acıbadem Mehmet Ali Aydınlar Üniversitesi, Sağlık Bilimleri Yüksekokulu, İstanbul, Türkiye \\ ${ }^{5}$ Acıbadem Atakent Hastanesi, Genel Cerrahi Kliniği, Meme Sağlığı ve Hastalıkları Bölümü, İstanbul, Türkiye \\ ${ }^{6}$ Özel Avşar Kliniği, İstanbul, Türkiye
}

\section{ÖZET}

Giriş ve Amaç: Kadın için önemli bir vücut belirleyicisi olan memenin kaybı, hastanın yaşam kalitesinde (YK) büyük bir bozulmaya yol açmaktadır. Bu morbiditenin ortadan kaldıııması ve YK'nın artırılması için meme başı koruyucu mastektomi (MBKM) geliştirilmiştir. Daha iyi kozmetik sonuçlar endoskopik MBKM'yi gündeme getirse de görüş alanındaki ve sert uçlu aletlerin kontrolündeki kısıtlılık, diseksiyon boşluğunu sağlamadaki zorluk robotik meme başı koruyucu mastektomiyi (rMBKM) doğurmuştur.

Gereç ve Yöntem: İnvaziv meme kanseri için DaVinci Xi (Intuitive Surgical, Sunnyvale, CA) ile 2018'de Acıbadem Mehmet Ali Aydınlar Üniversitesi, Senoloji Araştırma Enstitüsü afiliye hastanelerinde rMBKM yapılan üç hastanın kayıtları retrospektif olarak incelendi. Tüm memelerde ( $n=4)$ diseksiyona posteriordan başlanmıştı.

Bulgular: Birimde 2018-2019 yılları arasında 738 meme kanseri hastası ameliyat edilmiş olup MBKM oranı \%31,4 (n= 232) idi. Bu hastalardan üçüne DaVinci Xi robotik sistemi ile rMBKM yapılmıştı. Ameliyatlar bir hastada sol, bir hastada sağ, bir hastada ise çift taraflı yapılmıştı. Sadece 2 numaralı, neoadjuvan kemoterapi alan, hastada ameliyattan altı (drenler çekildikten üç) hafta sonra seroma gözlendi ve dört haftada düzeldi. Tüm hastalar için başka komplikasyon gözlenmedi. Ortanca 21 aylık takip süresinde lokorejyonel nüks veya metastaz görülmedi.

Sonuç: Tek kesiden robotik mastektomi subkutan plandan ziyade pre-pektoral plandan başlanarak kolay ve güvenli olarak gerçekleştirilebilir.

Anahtar Kelimeler: Meme, robotik cerrahi, minimal invaziv cerrahi

Doi: 10.47717/turkjsurg.2020.4771 